\title{
Extraction of Zinc and Manganese from Alkaline and Zinc-Carbon Spent Batteries by Citric-Sulphuric Acid Solution
}

\author{
Francesco Ferella, ${ }^{1}$ Ida De Michelis, ${ }^{1}$ Francesca Beolchini, ${ }^{2}$ Valentina Innocenzi, ${ }^{1}$ \\ and Francesco Vegliò ${ }^{1}$ \\ ${ }^{1}$ Department of Chemistry, Chemical Engineering and Materials, University of L'Aquila, Monteluco di Roio, 67040 L'Aquila, Italy \\ ${ }^{2}$ Department of Marine Sciences, Polytechnic Institute of Marche, Via Brecce Bianche, 60131 Ancona, Italy
}

Correspondence should be addressed to Francesco Ferella, francesco.ferella@univaq.it

Received 8 June 2010; Revised 15 September 2010; Accepted 15 September 2010

Academic Editor: Alírio Rodrigues

Copyright ( $) 2010$ Francesco Ferella et al. This is an open access article distributed under the Creative Commons Attribution License, which permits unrestricted use, distribution, and reproduction in any medium, provided the original work is properly cited.

\begin{abstract}
The paper is focused on the recovery of zinc and manganese from alkaline and zinc-carbon spent batteries. Metals are extracted by sulphuric acid leaching in the presence of citric acid as reducing agent. Leaching tests are carried out according to a $2^{4}$ full factorial design, and empirical equations for $\mathrm{Mn}$ and $\mathrm{Zn}$ extraction yields are determined from experimental data as a function of pulp density, sulphuric acid concentration, temperature, and citric acid concentration. The highest values experimentally observed for extraction yields were $97 \%$ of manganese and $100 \%$ of zinc, under the following operating conditions: temperature $40^{\circ} \mathrm{C}$, pulp density $20 \%$, sulphuric acid concentration $1.8 \mathrm{M}$, and citric acid $40 \mathrm{~g} \mathrm{~L}^{-1}$. A second series of leaching tests is also performed to derive other empirical models to predict zinc and manganese extraction. Precipitation tests, aimed both at investigating precipitation of zinc during leaching and at evaluating recovery options of zinc and manganese, show that a quantitative precipitation of zinc can be reached but a coprecipitation of nearly $30 \%$ of manganese also takes place. The achieved results allow to propose a battery recycling process based on a countercurrent reducing leaching by citric acid in sulphuric solution.
\end{abstract}

\section{Introduction}

The battery market is steadily increasing worldwide: this behaviour requires a new approach in the management of these devices once they are exhausted [1]. In many countries alkaline and zinc-carbon spent batteries were still landfilled or incinerated up to the end of 2008, instead of being recycled, recovering valuable secondary raw materials and avoiding dispersion of heavy metals in the environment. Several European Countries have autonomously developed national collection systems and infrastructures to collect and recycle all kinds of portable batteries, despite the old Directive 91/157/EEC EEC (and subsequent amending acts of Directives 93/86/EEC and 98/101/EC) that covered only batteries and accumulators containing more than $0.0005 \%$ mercury, more than $0.025 \%$ cadmium, and more than $0.4 \%$ lead (percentages by weight) [2]. These Countries have arranged a financing system that is able to cover all costs related to the recycling activities by applying a surcharge on battery selling price [1]. In 2007 members of the European Battery Recycling Association (EBRA) recycled about 31,079 tonnes of portable batteries and accumulators: compared to the previous year there was a little improvement $(30,865$ tonnes in 2006) [3]. In more detail, quantities of batteries recycled by EBRA's members were 26,941 tonnes $(\sim 87 \%)$ of primary alkaline, zinc-carbon and zinc-air batteries, 2,688 Ni-Cd, $611 \mathrm{Ni}-\mathrm{MH}, 764$ lithium (primary and rechargeable), and 75 tonnes button cells [3]. Concerning the Italian scenario, only batteries and accumulators covered by Directive 91/157/EEC were collected and recycled, while the zinc-carbon and alkaline ones were simply landfilled until 2008; valuable metals such as zinc and manganese can be recovered through recycling, as well as iron alloys and nonferrous scraps [4]. The use of recycled metals in battery production instead of primary resources would have a positive environmental impact through the reduction of energy consumption and minimization of pollution [2]. The purpose of the new European Directive 2006/66/EC is to 
reduce the quantity of spent batteries and accumulators disposed in an inadequate way, setting European targets for collection and recycling. The Directive is applied to all batteries and accumulators from September 2008: the ultimate disposal of portable, industrial, and automotive batteries and accumulators by incineration or landfilling is strictly prohibited. Thus, Member States shall achieve the following minimum collection rates: $25 \%$ by 26 September 2012 and $45 \%$ by 26 September 2016. Moreover, recycling processes shall achieve the following minimum efficiencies [2]:

(i) recycling of $65 \%$ by average weight of lead-acid batteries and accumulators, including recycling of the lead content to the highest degree that is technically feasible while avoiding excessive costs;

(ii) recycling of $75 \%$ by average weight of nickelcadmium batteries and accumulators, including recycling of the cadmium content to the highest degree that is technically feasible while avoiding excessive costs;

(iii) recycling of $50 \%$ by average weight of other waste batteries and accumulators.

Member States shall oblige producers, or third parties acting on their behalf, to finance any net cost arising from public information campaigns on the collection, treatment, and recycling of all waste portable batteries and accumulators.

Several processes for the recycling of batteries were proposed, mainly in Europe, both pyrometallurgical and hydrometallurgical [5]. Many patented processes work on industrial scale; hydrometallurgical processes are usually characterised by different pretreatment stages, followed by leaching and separation of different metals by electrolysis, liquid-liquid extraction, or selective precipitation. The Batenus process treats all types of batteries (except for button cells); copper, nickel, and cadmium are selectively recovered by ion exchange, whereas zinc and manganese are separated by liquid-liquid extraction and electrodeposited in two cells to obtain metallic zinc and manganese dioxide [6]. In the Recupyl process zinc and manganese are recovered as carbonates or other compounds [7]. Revabat process treats only zinc-carbon and alkaline batteries; after sorting, batteries are dismantled and treated by sulphuric acid solution, from which $\mathrm{Mn}$ and $\mathrm{Zn}$ are recovered as oxides or salts [8]. The Batrec process (pyrometallurgical) recycles every type of battery (except for the Ni-Cd ones). Batteries are pyrolysed at temperature of $700^{\circ} \mathrm{C}$, and mercury is recovered by distillation. Metallic components are reduced and smelted in the induction furnace at $1500^{\circ} \mathrm{C}$ : $\mathrm{Fe}$ and $\mathrm{Mn}$ remain in the melt and form a ferromanganese alloy, whilst zinc vaporises and is recovered by condensation [9]. Toro et al. [10] developed a patented process for the recycling of alkaline and zinc-carbon spent batteries, where the metals are leached in acid solution in the presence of carbohydrates as reducing agents; after purification of solution, metallic zinc and manganese dioxide are recovered by electrowinning. Alkaline and zinc-carbon batteries were characterized by several authors [11-14]. Concerning the selective recycling of alkaline batteries, Veloso et al. [15] proposed a process in which metals are leached by $\mathrm{H}_{2} \mathrm{SO}_{4}$ and $\mathrm{H}_{2} \mathrm{O}_{2}$; after that manganese and zinc are selectively precipitated by $\mathrm{KOH}$. De Souza and Tenório [12] described a similar process performed by an acid leaching, but zinc and manganese are simultaneously recovered as metallic zinc and manganese dioxide by electrowinning. Salgado et al. [16] investigated the separation of zinc and manganese by liquid-liquid extraction, after a leaching step with $\mathrm{H}_{2} \mathrm{SO}_{4}$, as well as Devi et al. [17]. De Michelis et al. [11] developed a statistical design in leaching of alkaline and zinc-carbon battery paste by using sulphuric acid and oxalic acid as reducing agent. Vatistas et al. [18] studied the recovery of zinc by a selective leaching of the anodic compartment of alkaline batteries: zinc is lastly recovered from sulphate solution by electrowinning. An acid leaching of battery paste was proposed by Ferella et al. [19]: zinc is recovered by electrolysis, whereas a blend of manganese oxides was obtained by roasting of the leaching solid residue. Sayilgan et al. [20] have studied leaching of battery samples (zinc-carbon, alkaline, and mixture of them) by sulphuric and hydrochloric acid in the presence of oxalic acid as reducing agent. $\mathrm{Xi}$ et al. [21] proposed a process for production of $\mathrm{Mn}-\mathrm{Zn}$ ferrites using spent alkaline batteries: the powder is leached by $\mathrm{H}_{2} \mathrm{SO}_{4}$ and $\mathrm{H}_{2} \mathrm{O}_{2}$ as reducing agent, then $\mathrm{NaOH}$ is used to adjust the $\mathrm{pH}$ value in the range 3-5. $\mathrm{Mn}$ and Fe salts are added to have the right molar ratio, and after precipitation with $\mathrm{NH}_{4} \mathrm{HCO}_{3}$ in $\mathrm{pH}$ range 6.0-9.5 the precipitate is calcined at $1150^{\circ} \mathrm{C}$ to obtain ferrite. The process of Nan et al. [22] is almost similar, but $\left(\mathrm{NH}_{4}\right)_{2} \mathrm{C}_{2} \mathrm{O}_{4}$ is used as precipitating agent. A very good review of current processes for treatment of alkaline and zinc-carbon spent batteries was written by Sayilgan et al. [23].

\section{Experimental}

The aim of the present work is to recover zinc and manganese from spent battery internal material by means of sulphuric acid leaching in presence of citric acid as reducing agent. Citric acid is a carboxylic acid produced in different ways: in the most important production route, cultures of Aspergillus niger are fed into a sucrose or glucose-containing medium. The source of sugar is usually corn steep liquor, molasses, hydrolyzed corn starch, or other inexpensive sugary solutions. After the solid matter is filtered out of the resulting solution, citric acid is isolated by precipitation with lime to yield calcium citrate salt, from which citric acid is regenerated by treatment with sulfuric acid [24]. In the present work citric acid was chosen considering both its high efficiency in the reductive dissolution of Mn (IV) and its cost, since it can be produced by fermentation of waste carbohydrates (for instance coming from processing of sugar beets). Experimental tests with sulphuric acid and citric acid were designed according to a full factorial design (four factors, two levels) [25]. Zinc(II) oxide can be quantitatively extracted by sulphuric acid, and the chemical reaction is the following:

$$
\mathrm{ZnO}+\mathrm{H}_{2} \mathrm{SO}_{4} \longrightarrow \mathrm{ZnSO}_{4}+\mathrm{H}_{2} \mathrm{O}
$$


TABLE 1: Experimental conditions of $2^{4}$ full factorial design.

\begin{tabular}{|c|c|c|c|c|c|c|c|c|c|}
\hline N. & Treat. & $\begin{array}{c}\text { A } \\
\text { Sulphuric acid }\end{array}$ & $\begin{array}{c}\text { B } \\
\text { Citric acid }\end{array}$ & $\begin{array}{c}\text { C } \\
\text { Temp. }\end{array}$ & $\begin{array}{c}\text { D } \\
\text { Pulp density }\end{array}$ & $\begin{array}{c}\mathrm{A} \\
(\mathrm{M})\end{array}$ & $\begin{array}{c}\mathrm{B} \\
\left(\mathrm{g} \mathrm{L}^{-1}\right)\end{array}$ & $\begin{array}{c}\mathrm{C} \\
\left({ }^{\circ} \mathrm{C}\right)\end{array}$ & $\begin{array}{c}\mathrm{D} \\
\left(\mathrm{g} \mathrm{L}^{-1}\right)\end{array}$ \\
\hline 1 & (1) & - & - & - & - & 0.9 & 7 & 40 & 100 \\
\hline 2 & $\mathrm{a}$ & + & - & - & - & 1.4 & 7 & 40 & 100 \\
\hline 3 & b & - & + & - & - & 0.9 & 20 & 40 & 100 \\
\hline 4 & $\mathrm{ab}$ & + & + & - & - & 1.4 & 20 & 40 & 100 \\
\hline 5 & c & - & - & + & - & 0.9 & 7 & 80 & 100 \\
\hline 6 & $\mathrm{ac}$ & + & - & + & - & 1.4 & 7 & 80 & 100 \\
\hline 7 & $\mathrm{bc}$ & - & + & + & - & 0.9 & 20 & 80 & 100 \\
\hline 8 & $a b c$ & + & + & + & - & 1.4 & 20 & 80 & 100 \\
\hline 9 & $\mathrm{~d}$ & - & - & - & + & 1.8 & 14 & 40 & 200 \\
\hline 10 & $\mathrm{ad}$ & + & - & - & + & 2.7 & 14 & 40 & 200 \\
\hline 11 & bd & - & + & - & + & 1.8 & 40 & 40 & 200 \\
\hline 12 & abd & + & + & - & + & 2.7 & 40 & 40 & 200 \\
\hline 13 & $\mathrm{~cd}$ & - & - & + & + & 1.8 & 14 & 80 & 200 \\
\hline 14 & acd & + & - & + & + & 2.7 & 14 & 80 & 200 \\
\hline 15 & bcd & - & + & + & + & 1.8 & 40 & 80 & 200 \\
\hline 16 & abcd & + & + & + & + & 2.7 & 40 & 80 & 200 \\
\hline 17 & 0 & 0 & 0 & 0 & 0 & 1.7 & 20 & 60 & 150 \\
\hline 18 & 0 & 0 & 0 & 0 & 0 & 1.7 & 20 & 60 & 150 \\
\hline
\end{tabular}

On the contrary, dissolution of manganese oxides such as $\mathrm{Mn}_{2} \mathrm{O}_{3}$ and $\mathrm{Mn}_{3} \mathrm{O}_{4}$ is partial because the produced $\mathrm{MnO}_{2}$ is insoluble, as shown by the following:

$$
\begin{gathered}
\mathrm{Mn}_{2} \mathrm{O}_{3}+\mathrm{H}_{2} \mathrm{SO}_{4} \longrightarrow \mathrm{MnO}_{2}+\mathrm{MnSO}_{4}+\mathrm{H}_{2} \mathrm{O} \\
\mathrm{Mn}_{3} \mathrm{O}_{4}+2 \mathrm{H}_{2} \mathrm{SO}_{4} \longrightarrow \mathrm{MnO}_{2}+2 \mathrm{MnSO}_{4}+2 \mathrm{H}_{2} \mathrm{O}
\end{gathered}
$$

Therefore a reducing agent is necessary to leach $\mathrm{Mn}(\mathrm{IV})$ [11, 16]; the reaction between manganese dioxide and citric acid in sulphuric acid solution can be described as follows:

$$
9 \mathrm{MnO}_{2}+9 \mathrm{H}_{2} \mathrm{SO}_{4}+\mathrm{C}_{6} \mathrm{H}_{8} \mathrm{O}_{7} \longrightarrow 9 \mathrm{MnSO}_{4}+6 \mathrm{CO}_{2}+13 \mathrm{H}_{2} \mathrm{O}
$$

The aim of the experimental leaching tests was to maximize the extraction yield of both zinc and manganese from battery powder. Afterward, several precipitation tests were carried out in order to evaluate the precipitation rate of zinc or manganese due to the high concentration of citric acid: in this approach citric acid can be used as reducing agent in the leaching stage and then as a precipitating agent in downstream step. The analysis of variance (ANOVA) was carried out on extraction yields both of $\mathrm{Mn}$ and $\mathrm{Zn}$ after $5 \mathrm{~h}$ of reaction, and empirical models were derived for both metals.

\section{Materials and Methods}

3.1. Battery Dismantling and Pretreatments. Spent alkaline and zinc-carbon batteries of different size from several manufacturers were manually dismantled. The black paste from each battery was extracted and separated from metallic scraps and plastic/paper films; afterward a sample was derived by mixing all the different samples, which are a mixture of the cathodic (manganese oxides and graphite) and the anodic (zinc oxides and electrolytic solution) materials. That paste, which was about $55 \%$ of the total battery weight, was dried for $24 \mathrm{~h}$ at $105^{\circ} \mathrm{C}$ for the determination of moisture. It was subsequently ground for 30 minutes by a ball mill and then sieved using a $500 \mu \mathrm{m}$ standard sieve. The powder obtained was washed with distilled water in a 1liter jacketed stirred reactor tank at $60^{\circ} \mathrm{C}$ for $1 \mathrm{~h}$ with $20 \%$ pulp density; that temperature was chosen to increase the solubility of $\mathrm{KOH}$ and $\mathrm{NH}_{4} \mathrm{Cl}$, which are the electrolytes of alkaline and $\mathrm{Zn}-\mathrm{C}$ batteries, respectively. The purpose of this neutral leaching was the removal of water-soluble compounds in order to reduce the consumption of sulphuric acid in the subsequent leaching step making a preliminary purification. Furthermore, concentrations of ammonium, chlorides, potassium as well as COD (chemical oxygen demand) were determined by UV-Vis spectrophotometer (CADAS 50, Dr Lange) by means of measuring kits by Dr. Lange. Washed powder was dried for $24 \mathrm{~h}$ at $105^{\circ} \mathrm{C}$ and weighted for determination of weight loss. All the leaching tests shown in this study were carried out with the washed powder. Original and washed powders were analyzed by Xray fluorescence (XRF, Spectro Xepos) and X-ray diffraction (XRD, Philips X-Pert).

A quantitative analysis was also carried out by atomic absorption spectrometry (AAS, spectrometer SpectrAA 200, Varian) in order to evaluate accurate percentages of manganese and zinc in the black powder. Quantitative analysis 
TABLE 2: Levels of factors investigated in the second series of leaching tests.

\begin{tabular}{|c|c|c|c|c|c|c|}
\hline \multirow[b]{2}{*}{ Factor } & & \multicolumn{5}{|c|}{ Level } \\
\hline & & $(-\alpha)$ & $(-1)$ & (0) & $(+1)$ & $(+\alpha)$ \\
\hline $\mathrm{A}$ & Sulphuric acid & $0.5 \mathrm{M}$ & $1 \mathrm{M}$ & $1.5 \mathrm{M}$ & $2 \mathrm{M}$ & $2.5 \mathrm{M}$ \\
\hline B & Citric acid & $0 \mathrm{M}$ & $0.075 \mathrm{M}$ & $0.15 \mathrm{M}$ & $0.225 \mathrm{M}$ & $0.3 \mathrm{M}$ \\
\hline $\mathrm{C}$ & Pulp density & $10 \%$ & $15 \%$ & $20 \%$ & $25 \%$ & $30 \%$ \\
\hline $\mathrm{D}$ & Temperature & $30^{\circ} \mathrm{C}$ & $40^{\circ} \mathrm{C}$ & $50^{\circ} \mathrm{C}$ & $60^{\circ} \mathrm{C}$ & $70^{\circ} \mathrm{C}$ \\
\hline
\end{tabular}

was performed in a microwave acid digestion bomb (ColeParmer AIM 600) where $1 \mathrm{~g}$ of washed powder was dissolved in $25 \mathrm{~mL}$ of aqua regia together with $0.4 \mathrm{~g}$ of glucose. Concentrated hydrochloric and nitric acid as well as glucose of analytical grade were used (Sigma Aldrich). At the end the pregnant solution was filtered to separate it from undissolved material and diluted in a $100 \mathrm{~mL}$ calibrated flask. Manganese and zinc were determined by AAS.

3.2. Leaching Tests with Sulphuric Acid and Citric Acid. In the present work, a $2^{4}$ full factorial design with a replicated central point was chosen for conducting the leaching tests where factors (low and high levels in parentheses) were sulphuric acid concentration (stoichiometric ratio, 1.5 stoichiometric ratio), citric acid concentration ( 0.5 stoichiometric ratio, 1.5 stoichiometric ratio), temperature $\left(40^{\circ} \mathrm{C}, 80^{\circ} \mathrm{C}\right)$, and pulp density $(10 \%, 20 \%)$. Stoichiometric ratios for sulphuric acid and citric acid were calculated according to reactions (1) and (3), considering zinc all as $\mathrm{ZnO}$ and manganese as $\mathrm{MnO}_{2}$. These levels were chosen to study a wide response surface area by the analysis of variance (ANOVA). The experimental conditions of each treatment are given in Table 1.

Tests were numbered in conformity with the Yates' algorithm. Two central point experiments (17-18) were carried out to have an independent estimation of the variance of experimental error and to test the adequacy of the models [25]. Leaching tests were performed in $250 \mathrm{~mL}$ closed flasks submerged in a thermostatically controlled water bath equipped with a mechanical stirrer (Dubnoff, ISCO). For each test the solution mixture was prepared by dissolving the required amount of analytical grade citric acid (supplied by Fluka) and washed battery powder in $100 \mathrm{~mL}$ of $\mathrm{H}_{2} \mathrm{SO}_{4}$ solution, according to the experimental plan. During each test, $1 \mathrm{~mL}$ of leach liquor was withdrawn after 1,3 , and $5 \mathrm{~h}$ to measure the concentration of $\mathrm{Mn}$ and $\mathrm{Zn}$ by AAS. Each sample was diluted $1: 10$ by a solution of nitric acid $(\mathrm{pH} \sim 2)$ to avoid precipitation of metals. At the end of each reaction the $\mathrm{pH}$ was measured by a digital $\mathrm{pH}$-meter (Mettler Toledo MP 220). The filtered residue was recovered and weighted by an analytical balance (Mettler PE 600) after drying at $105^{\circ} \mathrm{C}$ for $24 \mathrm{~h}$.

Zinc and manganese extraction yields at $5 \mathrm{~h}$ were worked out using ANOVA: in particular Yates' algorithm was used to evaluate whether effects and interactions among the investigated factors are significant with respect to the experimental error. The significance of main factors and their interactions was assessed by $F$-test method with a confidence level of
TABLE 3: List of tests of the second leaching campaign.

\begin{tabular}{|c|c|c|c|c|}
\hline $\begin{array}{l}\text { Test } \\
\text { No. }\end{array}$ & $\mathrm{H}_{2} \mathrm{SO}_{4}(\mathrm{M})$ & Citric acid (M) & Pulp density (\%) & $\mathrm{T}\left({ }^{\circ} \mathrm{C}\right)$ \\
\hline 1 & 1 & 0.075 & 15 & 40 \\
\hline 2 & 2 & 0.075 & 15 & 40 \\
\hline 3 & 1 & 0.225 & 15 & 40 \\
\hline 4 & 2 & 0.225 & 15 & 40 \\
\hline 5 & 1 & 0.075 & 25 & 40 \\
\hline 6 & 2 & 0.075 & 25 & 40 \\
\hline 7 & 1 & 0.225 & 25 & 40 \\
\hline 8 & 2 & 0.225 & 25 & 40 \\
\hline 9 & 1 & 0.075 & 15 & 60 \\
\hline 10 & 2 & 0.075 & 15 & 60 \\
\hline 11 & 1 & 0.225 & 15 & 60 \\
\hline 12 & 2 & 0.225 & 15 & 60 \\
\hline 13 & 1 & 0.075 & 25 & 60 \\
\hline 14 & 2 & 0.075 & 25 & 60 \\
\hline 15 & 1 & 0.225 & 25 & 60 \\
\hline 16 & 2 & 0.225 & 25 & 60 \\
\hline 17 & 0.5 & 0.150 & 20 & 50 \\
\hline 18 & 2.5 & 0.150 & 20 & 50 \\
\hline 19 & 1.5 & 0.000 & 20 & 50 \\
\hline 20 & 1.5 & 0.300 & 20 & 50 \\
\hline 21 & 1.5 & 0.150 & 10 & 50 \\
\hline 22 & 1.5 & 0.150 & 30 & 50 \\
\hline 23 & 1.5 & 0.150 & 20 & 30 \\
\hline 24 & 1.5 & 0.150 & 20 & 70 \\
\hline 25 & 1.5 & 0.150 & 20 & 50 \\
\hline 26 & 1.5 & 0.150 & 20 & 50 \\
\hline 27 & 1.5 & 0.150 & 20 & 50 \\
\hline 28 & 1.5 & 0.150 & 20 & 50 \\
\hline
\end{tabular}

95\%. Response surface methodology (RSM) was used for modelling zinc and manganese extraction yields after 5 -hour reaction $[25,26]$.

A second series of leaching tests were carried out to test for quadratic effects and to obtain more accurate models able to predict the extraction yield of zinc and manganese in the range of the tested conditions. Parameters of the models can be estimated by using proper experimental design while collecting data. The experimental design for fitting the second-order models was orthogonal and rotatable $[25,26]$. Choosing the right value of $\alpha$, the central composite design can be rotatable: $\alpha=(n)^{1 / 4}$, where $n$ is the number of points used in the factorial portion of the design, that is, 16 . The central point was replicated four times (tests 25-28) in order to have a good estimation of the experimental error, and eight axial tests were also carried out (tests 17-24). Samples were withdrawn after 3 and $5 \mathrm{~h}$, and the latter data were analyzed by ANOVA and used for regression analysis. The experimental plan is given in Table 2, whereas the tests are listed in Table 3. 
TABLE 4: Experimental conditions of the first series of precipitation tests: temperature $80^{\circ} \mathrm{C}$.

\begin{tabular}{lcccc}
\hline Test & $\begin{array}{c}\mathrm{Zn} \\
\left(\mathrm{g} \mathrm{L}^{-1}\right)\end{array}$ & $\begin{array}{c}\mathrm{Mn} \\
\left(\mathrm{g} \mathrm{L}^{-1}\right)\end{array}$ & $\begin{array}{c}\mathrm{C}_{6} \mathrm{H}_{8} \mathrm{O}_{7} \\
\left(\mathrm{~g} \mathrm{~L}^{-1}\right)\end{array}$ & $\begin{array}{c}\mathrm{H}_{2} \mathrm{SO}_{4} \\
(\mathrm{M})\end{array}$ \\
\hline 1 & 40 & 0 & 78 & 2.7 \\
2 & 40 & 40 & 78 & 2.7 \\
3 & 40 & 80 & 78 & 2.7 \\
4 & 40 & 0 & 157 & 2.7 \\
5 & 40 & 40 & 157 & 2.7 \\
6 & 40 & 80 & 157 & 2.7 \\
\hline
\end{tabular}

3.3. Precipitation Tests. Precipitation tests were performed to evaluate the precipitation rate of zinc and manganese which could have occurred during some of leaching tests of the full factorial design. Furthermore, precipitation by citric acid was investigated because it could also be used as a suitable way to recover zinc and/or manganese, since roasting of citrate at $300-450^{\circ} \mathrm{C}$ gives the corresponding metal oxide and nontoxic compounds in the exhausted gas, that is, water and carbon dioxide [27]:

$$
\begin{gathered}
\mathrm{Zn}_{3} \mathrm{C}_{12} \mathrm{H}_{10} \mathrm{O}_{14}+9 \mathrm{O}_{2} \longrightarrow 3 \mathrm{ZnO}+12 \mathrm{CO}_{2}+5 \mathrm{H}_{2} \mathrm{O} \\
\mathrm{Mn}_{3} \mathrm{C}_{12} \mathrm{H}_{10} \mathrm{O}_{14}+9 \mathrm{O}_{2} \longrightarrow 3 \mathrm{MnO}_{2}+12 \mathrm{CO}_{2}+5 \mathrm{H}_{2} \mathrm{O}
\end{gathered}
$$

Depending on temperature and air flow-rate, formation of mixed manganese oxides $\left(\mathrm{Mn}_{3} \mathrm{O}_{4}, \mathrm{Mn}_{2} \mathrm{O}_{3}\right)$ could also occur. These oxides can be leached by sulphuric acid and recovered as manganese carbonate by precipitation or even as metallic compound by electrowinning (cathodic deposition). This last technique can also be used for recovery of $\gamma$ $\mathrm{MnO}_{2}$ at the anode side from the same sulphate medium by changing electrolysis parameters. Experimental conditions of precipitation tests are given in Table 4 .

These tests were performed at $80^{\circ} \mathrm{C}$ by using aqueous synthetic solutions. The operating conditions were chosen as follows: $40 \mathrm{~g} \mathrm{~L}^{-1}$ of $\mathrm{Zn}$ (typical concentrations obtained by a leaching with $20 \%$ pulp density of battery powder) in a $2.7 \mathrm{M}$ sulphuric acid solution (which is equal to 1.5 stoichiometric ratio with $20 \%$ pulp density), temperature $80^{\circ} \mathrm{C}$, and reaction time $3 \mathrm{~h}$. Manganese concentration ranged from 0 to $80 \mathrm{~g} \mathrm{~L}^{-1}$. Synthetic solutions were prepared by dissolving the required amount of manganese sulphate, zinc sulphate, and citric acid and adjusting $\mathrm{pH}$ by a $2 \mathrm{M}$ sulphuric acid solution. Reagents were supplied by Fluka. Another series of precipitation tests was carried out at $40^{\circ} \mathrm{C}$ by using synthetic solutions as well. Conditions of the whole experimental plan are reported in Table 5 .

In this case no sulphuric acid was added to any flask, as previously done; in fact, the aim was to simulate some pregnant solutions in which acid is largely consumed at the end of leaching reaction.

\section{Results and Discussion}

4.1. Characterization of Battery Powder. Original powder showed a moisture content of around $6 \% \mathrm{w} / \mathrm{w}$, determined by weight loss after drying at $105^{\circ} \mathrm{C}$. Once that powder was leached by water for $1 \mathrm{~h}, \mathrm{pH}$ of pregnant solution was 11.6, confirming dissolution of $\mathrm{KOH}$. The removal of chlorides and potassium was $96 \%$ and $89 \%$, respectively. AAS analysis highlighted that no $\mathrm{Zn}$ and $\mathrm{Mn}$ were leached by this neutral leaching. After drying at $105^{\circ} \mathrm{C}$ the weight loss of the sample was $9.5 \%$. Concentration of ammonium in the neutral leaching solution was $105 \mathrm{mg} \mathrm{L}^{-1}$, chlorides $265 \mathrm{mg} \mathrm{L}^{-1}$, potassium $1800 \mathrm{mg} \mathrm{L}^{-1}$, and COD equal to $470 \mathrm{mg} \mathrm{L}^{-1}$. Concentration of $\mathrm{NH}_{4}{ }^{+}$seems to be rather low, but this is probably due to the temperature of washing $\left(60^{\circ} \mathrm{C}\right)$ which could have promoted evaporation of ammonia: in fact, free ammonia is predominant in aqueous solution at alkaline $\mathrm{pH}$. XRF of original, and washed powder is reported in Table 6.

Data of washed powder show a significant amount of $\mathrm{Zn}$ and $\mathrm{Mn}$, which represent more than $50 \%$ of the total mass. The balance mainly consists of carbon (graphite-containing cathodes), oxygen, and nitrogen.

XRD spectrum of original sample is not so clear because the structure of compounds is not crystalline and counts are very low. The most probable phases identified were $\mathrm{ZnO}, \mathrm{Mn}_{2} \mathrm{O}_{3}, \mathrm{Mn}_{3} \mathrm{O}_{4}$, graphite, $\mathrm{KOH}$, unreacted $\mathrm{MnO}_{2}$, and one zinc-chlorine compound in the original powder, and the same phases except for $\mathrm{K}$ and $\mathrm{Cl}$ complexes in the washed powder (see Figure 1). Spectrum of washed powder evidences the probable presence of $\mathrm{Fe}_{2} \mathrm{O}_{3}$ that could be covered by other compounds in the original spectrum. Results of quantitative analysis by AAS indicated $40.8 \%$ and $25.2 \% \mathrm{w} / \mathrm{w}$ of $\mathrm{Mn}$ and $\mathrm{Zn}$, respectively.

4.2. Leaching Tests. Experimental results expressed in terms of manganese and zinc extraction after $5 \mathrm{~h}$ are shown below. Figure 2 reports the results of tests carried out at $40^{\circ} \mathrm{C}$, whilst Figure 3 shows results of the same tests at $80^{\circ} \mathrm{C}$.

As regards kinetics, at $40^{\circ} \mathrm{C}$ both $\mathrm{Mn}$ and $\mathrm{Zn}$ dissolution improves with time, although the difference between yields at 1 and $5 \mathrm{~h}$ is not so high. At $80^{\circ} \mathrm{C}$, except for a couple of points, the final $\mathrm{Mn}$ and $\mathrm{Zn}$ extraction yield is already achieved after $1 \mathrm{~h}$. It can be noted that the maximum simultaneous extraction yield for $\mathrm{Mn}$ and $\mathrm{Zn}(100 \%)$ was obtained in tests 7 by a stoichiometric amount of sulphuric acid $(0.9 \mathrm{M}), 1.5$ stoichiometric amount of citric acid $\left(20 \mathrm{~g} \mathrm{~L}^{-1}\right)$ at $80^{\circ} \mathrm{C}$ with $10 \%$ pulp density. The same simultaneous extraction yield was reached in test 8 , where a greater amount of $\mathrm{H}_{2} \mathrm{SO}_{4}$ was used with respect to tests 7 . Similar yield was obtained in tests 11 and 12 at $40^{\circ} \mathrm{C}$ with a double pulp density (20\%). Comparing results of tests 11-12 to those of tests 15-16, it can be noted that extraction of zinc in the latter two tests is lower, being around 64-67\%: it can be inferred that the solubility of zinc citrate decreases with temperature. This phenomenon was already observed in another experimental campaign carried out on alkaline and zinc-carbon batteries by using oxalic acid: extraction yields of $\mathrm{Zn}$ were always lower 

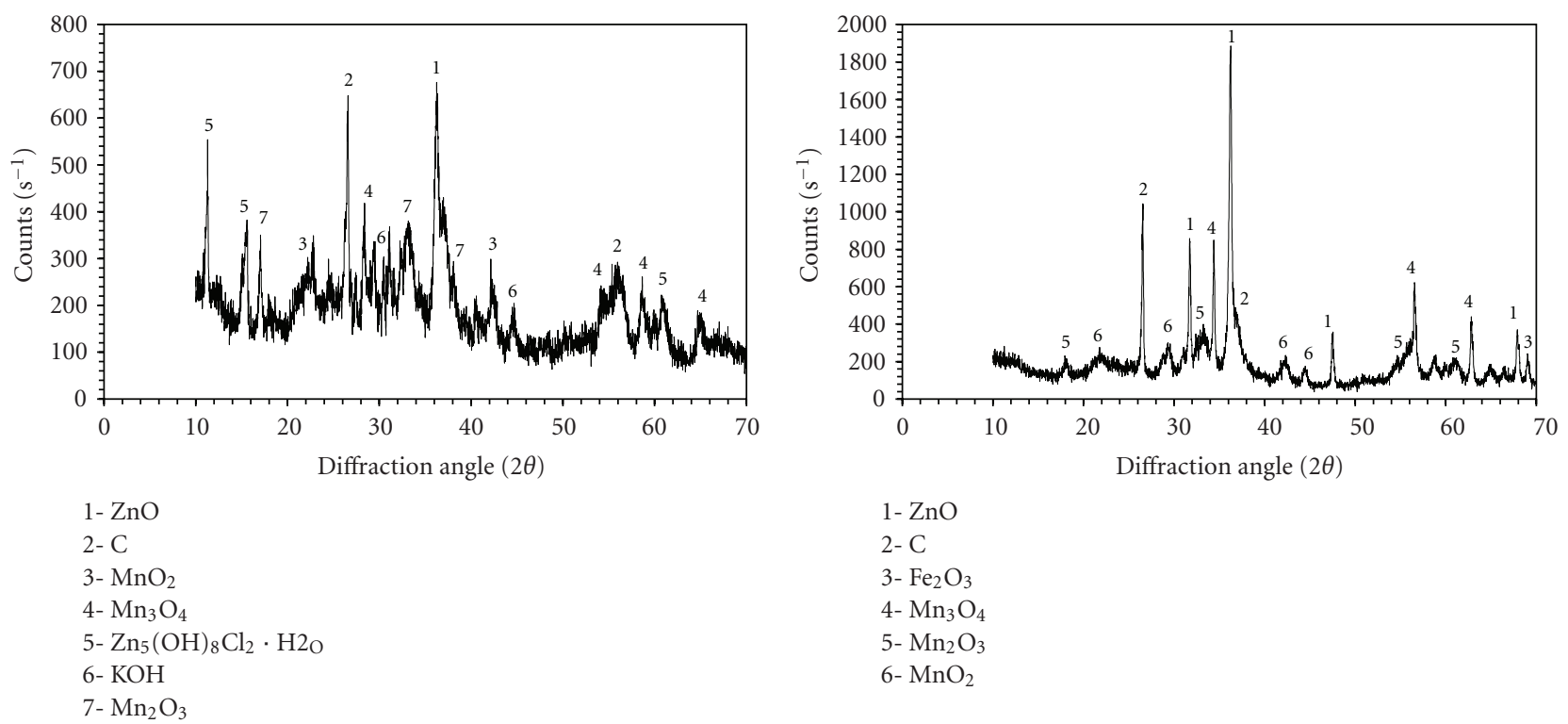
1- $\mathrm{ZnO}$
2- $\mathrm{C}$
3- $\mathrm{Fe}_{2} \mathrm{O}_{3}$
4- $\mathrm{Mn}_{3} \mathrm{O}_{4}$
5- $\mathrm{Mn}_{2} \mathrm{O}_{3}$
6- $\mathrm{MnO}_{2}$

(a)

(b)

FIGURE 1: XRD pattern of original (a) and washed (b) powder.

than $10 \%$ by using $50 \%$ stoichiometric excess of oxalic acid as reducing agent [11].

It can also be observed from the data that manganese contained in batteries needs a certain amount of citric acid: extraction yields of that metal in tests carried out with the lowest level of factor B (citric acid concentration) were no greater than $80 \%$ with $20 \%$ pulp density. In tests with pulp density equal to $10 \%$, the extraction of $\mathrm{Mn}$ was even $30 \%$. This can easily be understood since $\mathrm{Mn}(\mathrm{IV})$ needs citric acid to be reduced to $\mathrm{Mn}(\mathrm{II})$ becoming soluble in $\mathrm{H}_{2} \mathrm{SO}_{4}$ solution. Replicated tests of central point confirm that manganese extraction is maximum if citric acid is at least equal to the required stoichiometric amount.

4.3. ANOVA and Regression Analysis. The ANOVA processing results at $5 \mathrm{~h}$ are shown in Figure 4.

Broken lines in Figure 4 represent the value of $\mathrm{Mn}$ and $\mathrm{Zn}$ effects which matches 95\% significance level: it means that every effect higher than those lines is significant, according to $F$-test utilized. The corresponding lines on the negative plane are also shown.

As it is possible to note, the most significant effects affecting Mn extraction are four: citric acid concentration (factor B) has a strong positive effect on dissolution of insoluble manganese, as expected, because of the reason mentioned above. Temperature (factor C) has a positive effect, thus an increase from 40 to $80^{\circ} \mathrm{C}$ results in better extraction. Pulp density (factor D) has likewise positive influence on manganese dissolution, taking the other factors unchanged. Interaction between factor $\mathrm{C}$ and $\mathrm{D}$ is also significant, although negative: hence, increasing both temperature and pulp density, the extraction of manganese is lower. This fact confirms that the solubility of manganese citrate decreases with temperature, since with $20 \%$ pulp density the amount of manganese into solution is greater. Sulphuric acid (factor A) seems not to be significant: it means that the stoichiometric concentration $(0.9 \mathrm{M}$ and $1.8 \mathrm{M}$ if pulp density is $10 \%$ and $20 \%$, resp.) is enough to extract all manganese.

Concerning zinc extraction, significant factors are four: pulp density (BD) is negative; this means that increasing at the same time the two factors zinc extraction yield decreases; this can be related to the solubility of zinc citrate which partially precipitates with very high concentration of zinc and citric acid into solution. Interaction of temperature and pulp density (CD) is negative, as well as that one among citric acid concentration, temperature, and pulp density (BCD). A negative effect of interaction $C D$ can indeed be due to inverse solubility of zinc citrate, which is greater at lower temperatures.

ANOVA results were used to derive two empirical models in order to predict manganese and zinc extraction yields in a wide range of operating conditions that were not directly investigated, even though between the limits given in Table 1 for each factor. According to that analysis, the following equations were then used in order to predict zinc and manganese extraction yield as a function of sulphuric and citric acid concentration, temperature, and pulp density:

$$
\begin{aligned}
Y_{\mathrm{Zn}}= & 0.823+0.091 X_{4}-0.080 X_{2} X_{4} \\
& -0.129 X_{3} X_{4}-0.055 X_{2} X_{3} X_{4}, \\
Y_{\mathrm{Mn}}= & 0.763+0.148 X_{2}+0.069 X_{3}+0.109 X_{4}-0.063 X_{3} X_{4} .
\end{aligned}
$$

Mathematical equations able to fit the experimental leaching data are then empirical first-order models. The coefficients of equations were calculated by regression analysis, in which 


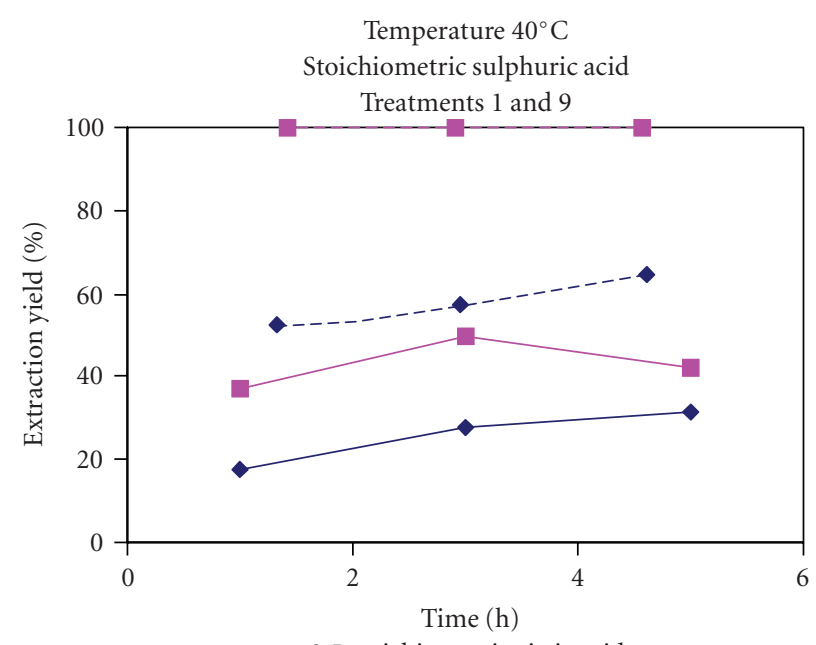

0.5 stoichiometric citric acid

(a)

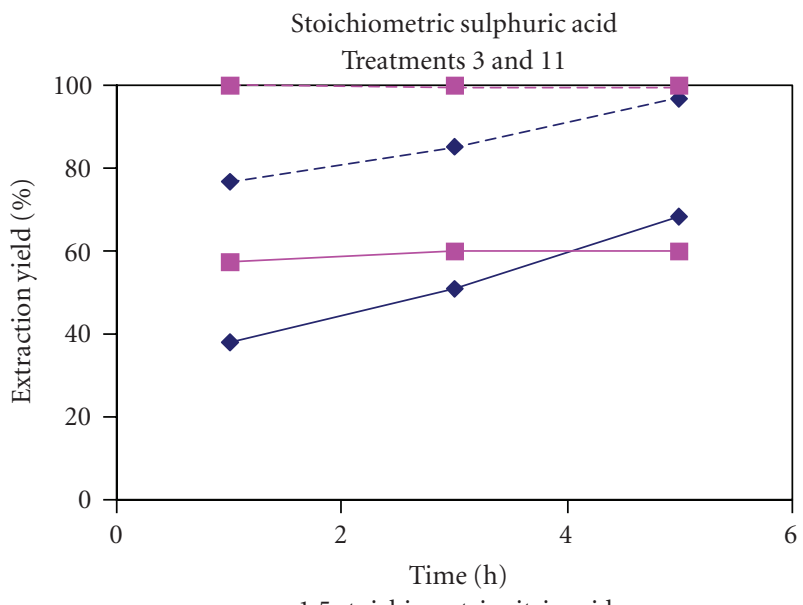

1.5 stoichiometric citric acid

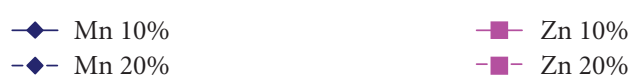

(c)

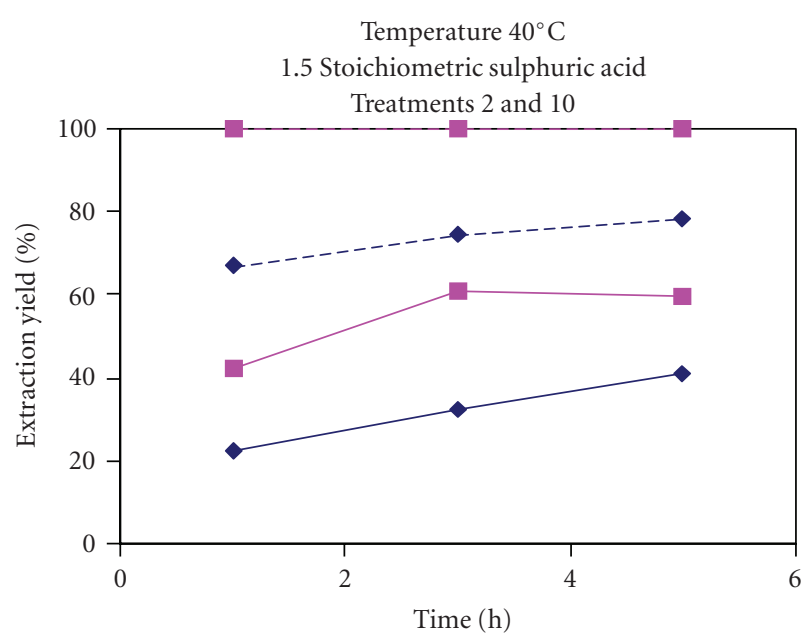

0.5 stoichiometric citric acid

(b)

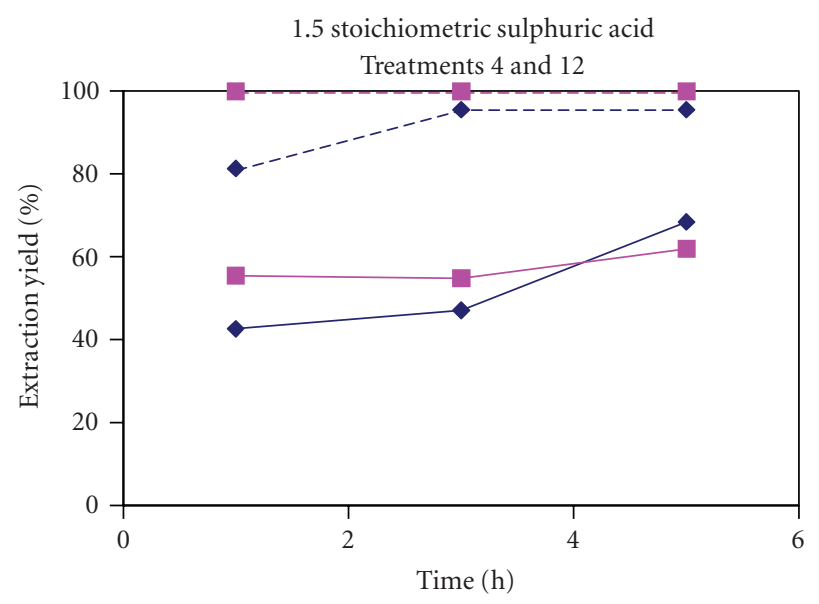

1.5 stoichiometric citric acid

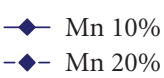

- Zn $10 \%$
$-\square-$ Zn $20 \%$

(d)

Figure 2: Zinc and manganese extraction yields versus time profiles during exhaust battery powder leaching by sulphuric acid solution in the presence of citric acid as reducing agent (temperature $40^{\circ} \mathrm{C}$ ). See Table 1 for experimental conditions (continuous lines are related to treatments with $10 \%$ powder, dotted lines to treatments with $20 \%$ powder).

factors and interactions with significance lower than $95 \%$ were not considered; $X_{1}, X_{2}, X_{3}, X_{4}$ are the dimensionless coded factors corresponding to the real four tested factors. Relations between coded and actual values are as follows:

$$
\begin{aligned}
& X_{1}=\frac{\mathrm{A}-1.25}{0.25}, \\
& X_{2}=\frac{\mathrm{B}-1}{0.5}, \\
& X_{3}=\frac{\mathrm{C}-60}{20}, \\
& X_{4}=\frac{\mathrm{D}-15}{5},
\end{aligned}
$$

where $\mathrm{A}$ is sulphuric acid concentration (expressed as stoichiometric ratio multiples, for instance, 1.5 means $+50 \%$ stoichiometric excess), $\mathrm{B}$ is citric acid concentration (stoichiometric ratio multiples), $\mathrm{C}$ is temperature $\left({ }^{\circ} \mathrm{C}\right)$, and $\mathrm{D}$ is pulp density $(\% \mathrm{w} / \mathrm{v})$.

However, the above models did not fit adequately the experimental data, as the correlation coefficient $R^{2}$ both for zinc and manganese is rather low $(\sim 0.85)$.

To obtain appropriate models useful for optimization purposes, an additional series of experimental tests were performed; in particular, eight axial and replicated central point tests were needed to build a second-order polynomial which could well fit the real response for a relatively small region of the independent variables.

4.4. Second Series of Leaching Tests: Results and ANOVA Analysis. Results of the second series of leaching experiments after $5 \mathrm{~h}$ of reaction are given in Table 7 , in terms of $\mathrm{Zn}$ and 


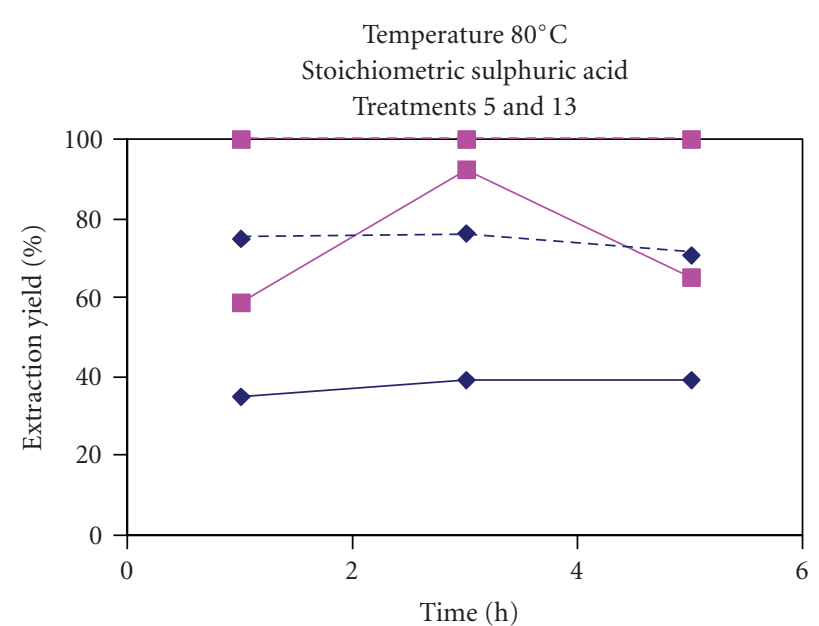

0.5 stoichiometric citric acid

(a)

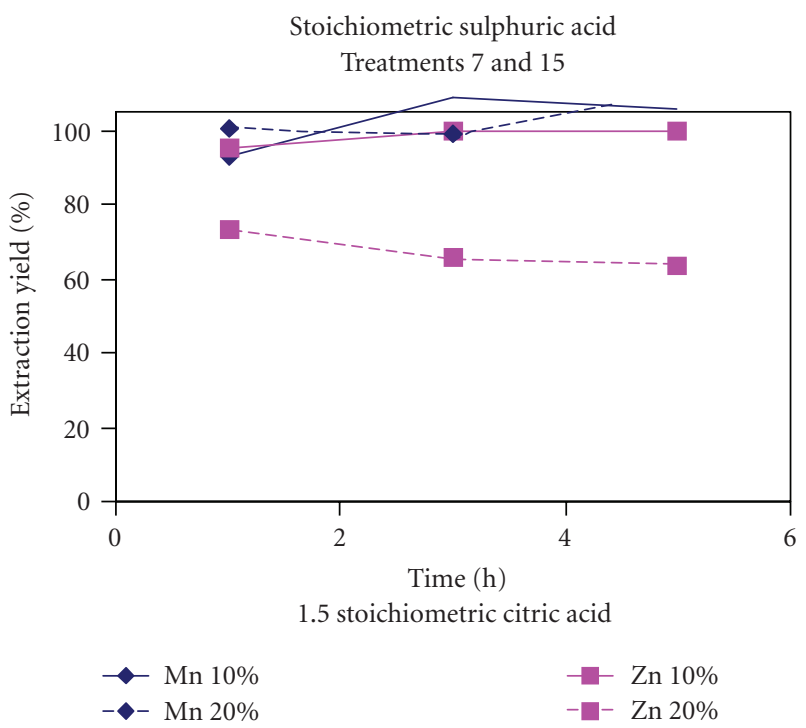

(c)

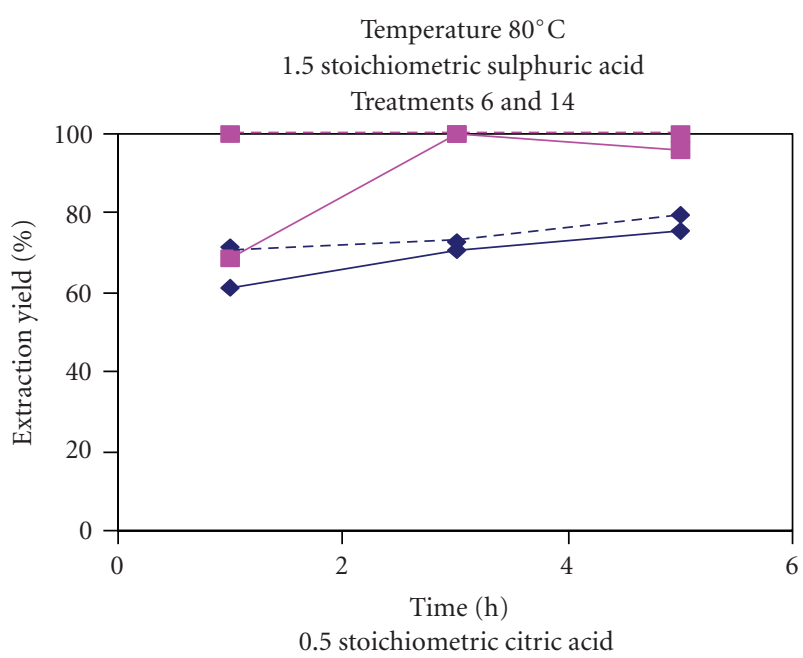

(b)

1.5 stoichiometric sulphuric acid Treatments 8 and 16

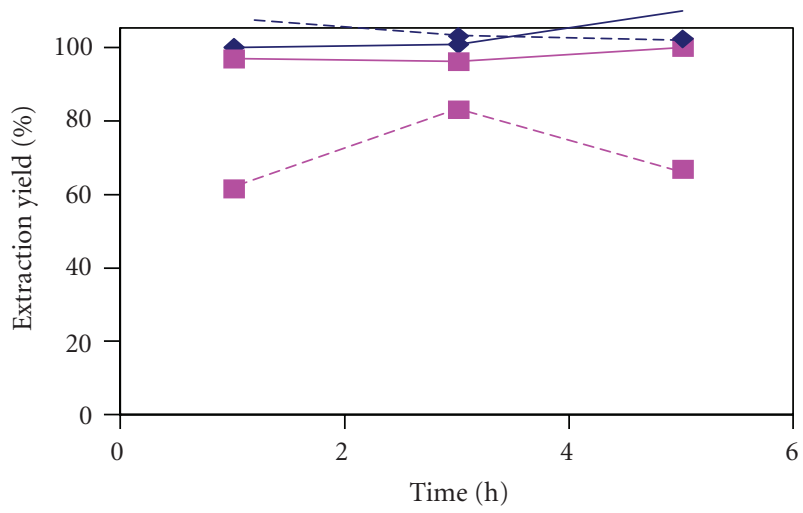

1.5 stoichiometric citric acid

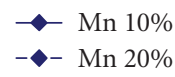

- Zn $10 \%$
$-\square-$ Zn $20 \%$

(d)

FIGURE 3: Zinc and manganese extraction yields versus time profiles during exhaust battery powder leaching by sulphuric acid solution in the presence of citric acid as reducing agent (temperature $80^{\circ} \mathrm{C}$ ). See Table 1 for experimental conditions (continuous lines are related to treatments with $10 \%$ powder, dotted lines to treatments with $20 \%$ powder).

Mn concentration as well as of extraction yield with respect to original content of the battery powder.

The best zinc extraction was obtained in test 10 (94.2\%) by using $2 \mathrm{~mol} \mathrm{~L}^{-1}$ of $\mathrm{H}_{2} \mathrm{SO}_{4}, 0.075 \mathrm{~mol} \mathrm{~L}^{-1}$ of citric acid at $60^{\circ} \mathrm{C}$ with $150 \mathrm{~g} \mathrm{~L}^{-1}$ of battery powder; the best extraction of manganese $\left(82.3 \%\right.$ ) was achieved in test 4 by $2 \mathrm{~mol} \mathrm{~L}^{-1}$ of $\mathrm{H}_{2} \mathrm{SO}_{4}, 0.225 \mathrm{~mol} \mathrm{~L}^{-1}$ of citric acid at $40^{\circ} \mathrm{C}$ with $150 \mathrm{~g} \mathrm{~L}^{-1}$ of battery powder.

It can be inferred from ANOVA that the main factors and interactions which mainly influence the final extraction of zinc (in the range of the investigated variables) are citric acid concentration, pulp density and temperature, sulphuric acid concentration-temperature, and pulp density-temperature. As regards manganese, the most significant factors are sulphuric acid concentration, citric acid, as expected, and pulp density, whereas temperature seems not to be significant if increases from 40 to $60^{\circ} \mathrm{C}$. A regression analysis was carried out to derive a useful tool able to calculate the final $\mathrm{Zn}$ and Mn extraction yield even for conditions not directly tested:

$$
\begin{aligned}
Y_{\mathrm{Zn}}(\%)= & 207.5-49.4 X_{2}-6.84 X_{3}-2.27 X_{4} \\
& +0.36 X_{1} X_{4}+0.094 X_{3} X_{4}, \\
Y_{\mathrm{Mn}}(\%)= & 93.1+27.6 X_{1}+53.1 X_{2}-7.55 X_{3}+0.132 X_{3}{ }^{2} .
\end{aligned}
$$

Comparison between the experimental extraction yields of manganese and zinc and those obtained by using equations above is shown in the scatter diagram. 


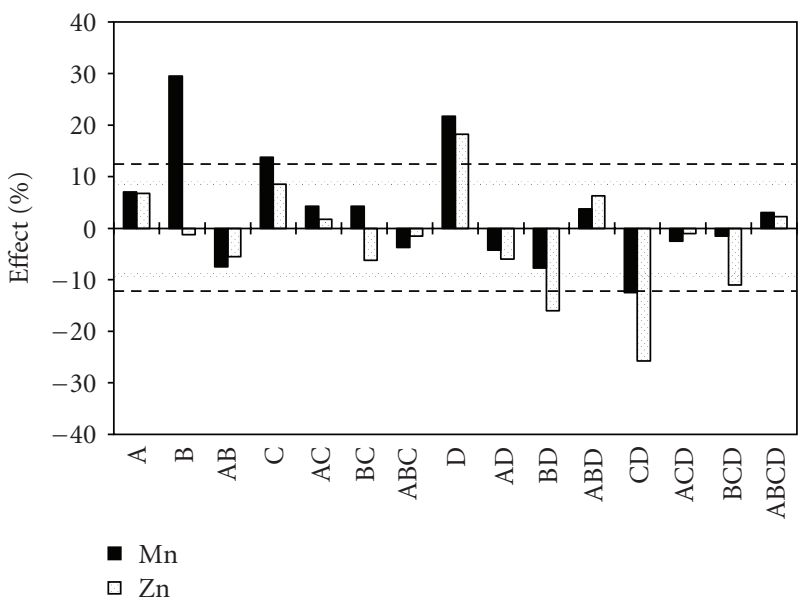

FIgURe 4: Effect of most significant factors and of their interactions on $\mathrm{Mn}$ and $\mathrm{Zn}$ extraction yield at $5 \mathrm{~h}$ (A: sulphuric acid concentration; B: citric acid concentration; C: temperature; D: pulp density).

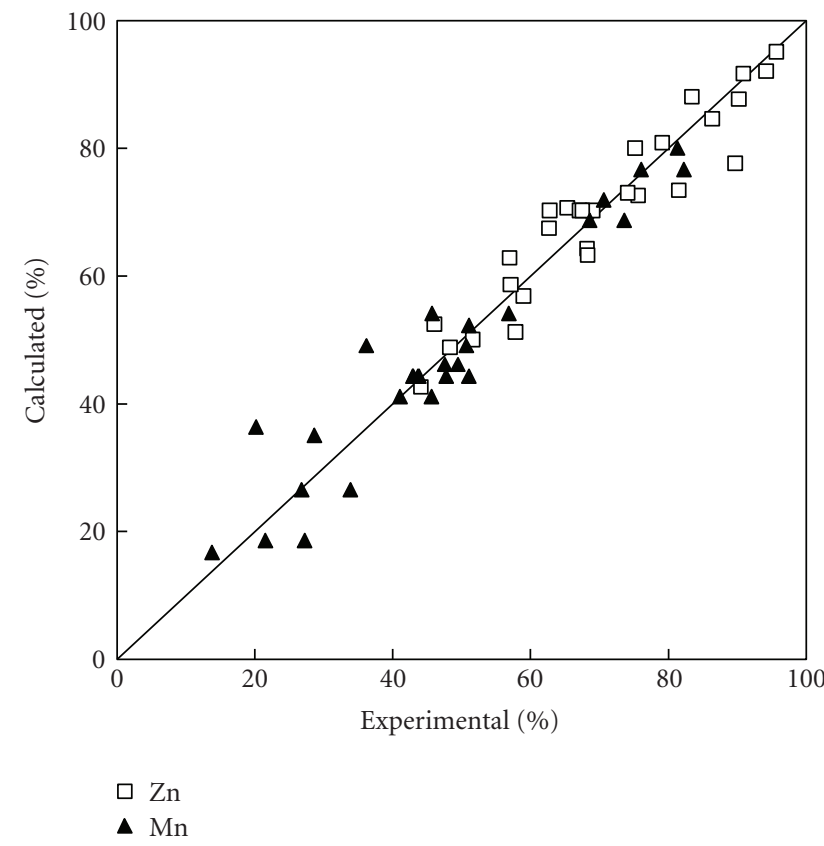

FIGURE 5: Scatter diagram of the experimental extraction yields at $5 \mathrm{~h}$ versus those calculated by (7).

It can be noted that the experimental data are well fitted by (7), confirming that the models interpret the experimental range investigated adequately; correlation coefficient $R^{2}$ is around 0.91 both for zinc and manganese.

4.5. Precipitation Tests. To make a hypothesis about precipitation mechanism, the solubility of zinc and manganese citrate has to be considered. Unfortunately, it was not possible to find neither zinc nor manganese solubility product. Even producers of chemicals were not able to give the requested values. Results of the first series of precipitation tests are given in Figure 6.
TABLE 5: Experimental conditions of the second series of precipitation tests: temperature $40^{\circ} \mathrm{C}$ without sulphuric acid.

\begin{tabular}{|c|c|c|c|}
\hline Test & $\begin{array}{c}\mathrm{C}_{6} \mathrm{H}_{8} \mathrm{O}_{7} \\
\left(\mathrm{~g} \mathrm{~L}^{-1}\right)\end{array}$ & $\begin{array}{c}\mathrm{Zn} \\
\left(\mathrm{g} \mathrm{L}^{-1}\right)\end{array}$ & $\begin{array}{c}\mathrm{Mn} \\
\left(\mathrm{g} \mathrm{L}^{-1}\right)\end{array}$ \\
\hline 1 & 0 & 0 & 0 \\
\hline 2 & 80 & 0 & 0 \\
\hline 3 & 160 & 0 & 0 \\
\hline 4 & 0 & 40 & 0 \\
\hline 5 & 80 & 40 & 0 \\
\hline 6 & 160 & 40 & 0 \\
\hline 7 & 0 & 80 & 0 \\
\hline 8 & 80 & 80 & 0 \\
\hline 9 & 160 & 80 & 0 \\
\hline 10 & 0 & 0 & 20 \\
\hline 11 & 80 & 0 & 20 \\
\hline 12 & 160 & 0 & 20 \\
\hline 13 & 0 & 40 & 20 \\
\hline 14 & 80 & 40 & 20 \\
\hline 15 & 160 & 40 & 20 \\
\hline 16 & 0 & 80 & 20 \\
\hline 17 & 80 & 80 & 20 \\
\hline 18 & 160 & 80 & 20 \\
\hline 19 & 0 & 0 & 40 \\
\hline 20 & 80 & 0 & 40 \\
\hline 21 & 160 & 0 & 40 \\
\hline 22 & 0 & 40 & 40 \\
\hline 23 & 80 & 40 & 40 \\
\hline 24 & 160 & 40 & 40 \\
\hline 25 & 0 & 80 & 40 \\
\hline 26 & 80 & 80 & 40 \\
\hline 27 & 160 & 80 & 40 \\
\hline
\end{tabular}

Table 6: Semiquantitative analysis of the original and washed powder.

\begin{tabular}{lcc}
\hline Element & $\begin{array}{c}\text { Original powder } \\
\%(w / w)\end{array}$ & $\begin{array}{c}\text { Washed powder } \\
\%(w / w)\end{array}$ \\
\hline $\mathrm{Mn}$ & 33.59 & 35.59 \\
$\mathrm{Zn}$ & 15.46 & 18.58 \\
$\mathrm{Fe}$ & 0.50 & 0.49 \\
$\mathrm{Cr}$ & 0.19 & 0.20 \\
$\mathrm{Al}$ & 0.36 & 0.19 \\
$\mathrm{~K}$ & 3.26 & 0.36 \\
$\mathrm{Cl}$ & 3.38 & 0.13 \\
$\mathrm{Ti}$ & 0.27 & 0.26 \\
$\mathrm{Si}$ & 0.49 & 0.42 \\
Balance & 42.50 & 43.78 \\
\hline
\end{tabular}

Looking at Figure 6, it is clear that the maximum precipitation is already reached after $1 \mathrm{~h}$ : concentration of both $\mathrm{Mn}$ and $\mathrm{Zn}$ does not change so much within $4 \mathrm{~h}$. Precipitation of $\mathrm{Zn}$ is always lower than 20\%; on the contrary, there is a significant precipitation of $\mathrm{Mn}$ which was not observed in none of the leaching tests. Obviously 


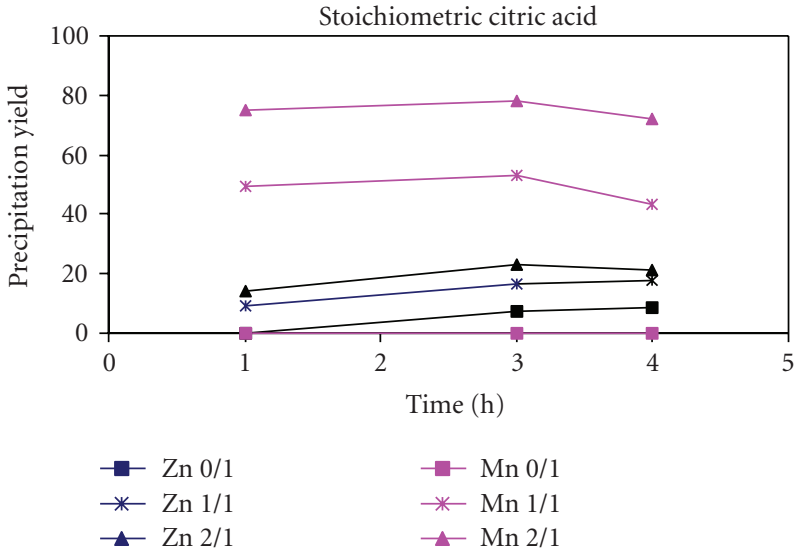

(a)

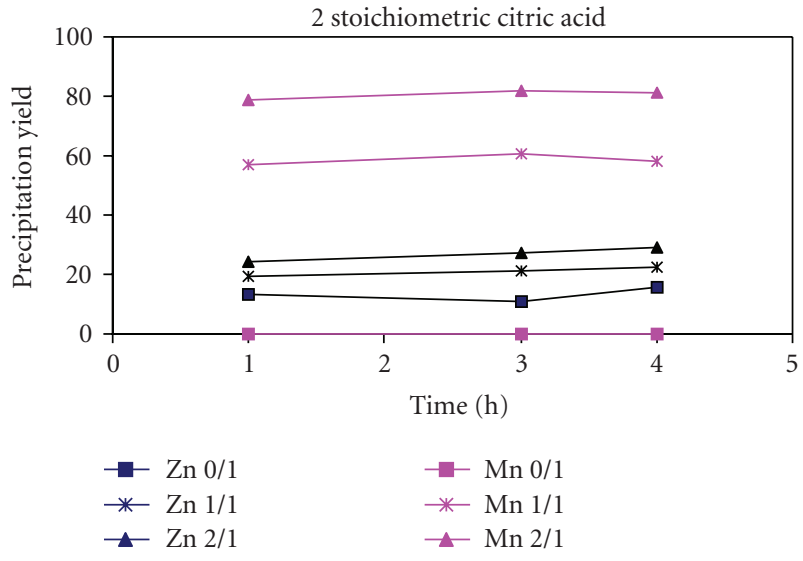

(b)

FIgURe 6: Precipitation trend of $\mathrm{Zn}$ and $\mathrm{Mn}$ in the first series of precipitation tests.

TABLE 7: Second series of leaching experiments: concentrations and extraction yields.

\begin{tabular}{|c|c|c|c|c|}
\hline Test & $\begin{array}{c}\mathrm{Zn} \\
\text { concentration } \\
\left(\mathrm{g} \mathrm{L}^{-1}\right)\end{array}$ & $\begin{array}{l}\text { Zn extraction } \\
\text { yield (\%) }\end{array}$ & $\begin{array}{c}\mathrm{Mn} \\
\text { concentration } \\
\left(\mathrm{g} \mathrm{L}^{-1}\right)\end{array}$ & $\begin{array}{c}\mathrm{Mn} \\
\text { extraction } \\
\text { yield }(\%)\end{array}$ \\
\hline 1 & 35.0 & 79.1 & 23.4 & 41.1 \\
\hline 2 & 42.3 & 95.6 & 39.1 & 68.6 \\
\hline 3 & 36.1 & 81.5 & 20.6 & 36.2 \\
\hline 4 & 39.9 & 90.2 & 46.9 & 82.3 \\
\hline 5 & 38.1 & 51.6 & 25.9 & 27.2 \\
\hline 6 & 50.3 & 68.2 & 47.1 & 49.5 \\
\hline 7 & 32.5 & 44.1 & 32.2 & 33.9 \\
\hline 8 & 43.5 & 59.0 & 43.4 & 45.7 \\
\hline 9 & 28.9 & 65.3 & 26.0 & 45.6 \\
\hline 10 & 41.7 & 94.2 & 42.0 & 73.6 \\
\hline 11 & 30.2 & 68.3 & 28.9 & 50.7 \\
\hline 12 & 38.2 & 86.4 & 43.4 & 76.1 \\
\hline 13 & 42.1 & 57.1 & 20.4 & 21.5 \\
\hline 14 & 55.4 & 75.2 & 45.2 & 47.6 \\
\hline 15 & 42.7 & 57.8 & 25.5 & 26.8 \\
\hline 16 & 55.8 & 75.6 & 54.1 & 56.9 \\
\hline 17 & 27.2 & 46.1 & 10.5 & 13.8 \\
\hline 18 & 49.2 & 83.4 & 53.7 & 70.6 \\
\hline 19 & 52.9 & 89.7 & 15.3 & 20.2 \\
\hline 20 & 33.6 & 57.1 & 38.8 & 51.1 \\
\hline 21 & 26.8 & 90.9 & 30.9 & 81.3 \\
\hline 22 & 42.8 & 48.3 & 32.7 & 28.7 \\
\hline 23 & 37.0 & 62.7 & 32.7 & 43.0 \\
\hline 24 & 43.7 & 74.1 & 36.3 & 47.8 \\
\hline 25 & 37.0 & 62.8 & 32.6 & 42.9 \\
\hline 26 & 39.6 & 67.1 & 33.2 & 43.7 \\
\hline 27 & 40.7 & 69.0 & 38.8 & 51.1 \\
\hline 28 & 39.8 & 67.5 & 33.3 & 43.8 \\
\hline
\end{tabular}

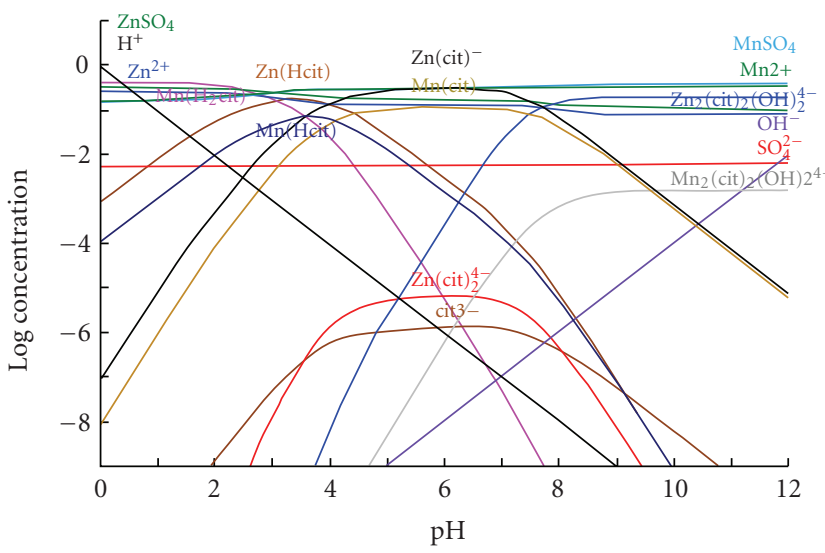

Figure 7: Solubility diagram of manganese, zinc, and citrate ions in aqueous solution at different $\mathrm{pHs}$ (concentration expressed as molarity; initial ion concentrations: $\mathrm{Mn}^{2+} 730 \mathrm{mM} ; \mathrm{Zn}^{2+} 610 \mathrm{mM}$; $\mathrm{C}_{6} \mathrm{H}_{5} \mathrm{O}_{7}{ }^{3-} 417 \mathrm{mM} ; \mathrm{SO}_{4}{ }^{2-} 500 \mathrm{mM}$; temperature $25^{\circ} \mathrm{C}$ ).

the precipitation rate increases with the amount of $\mathrm{Mn}$ dissolved into solution, and the residual concentration is always around $15-20 \mathrm{~g} \mathrm{~L}^{-1}$ : these values depend on solubility of manganese citrate corresponding to certain conditions. Regarding zinc, the maximum precipitation obtained is $20 \%$, which corresponds to a concentration around $30 \mathrm{~g} \mathrm{~L}^{-1}$ : that value is the same measured in leaching solution of tests 3-4 and 15-16, when a precipitation of zinc citrate could have been present. Since solubility products of $\mathrm{Mn}$ and $\mathrm{Zn}$ are available nowhere, a diagram by Medusa software [28] was obtained (Figure 7), where the temperature is fixed at $25^{\circ} \mathrm{C}$.

It can be inferred from the diagram that zinc citrate is more soluble than manganese citrate at $25^{\circ} \mathrm{C}$ : this is in accordance with results obtained in the first series of precipitation tests, even though the temperature was $80^{\circ} \mathrm{C}$. From this point of view it seems that the ratio between the two solubilities is still the same even increasing the temperature. Moreover, the solubility of both salts increases 


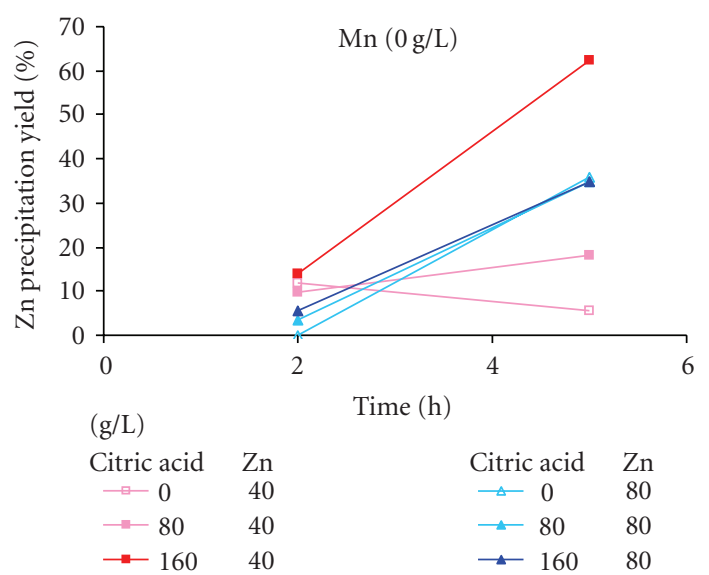

(a)

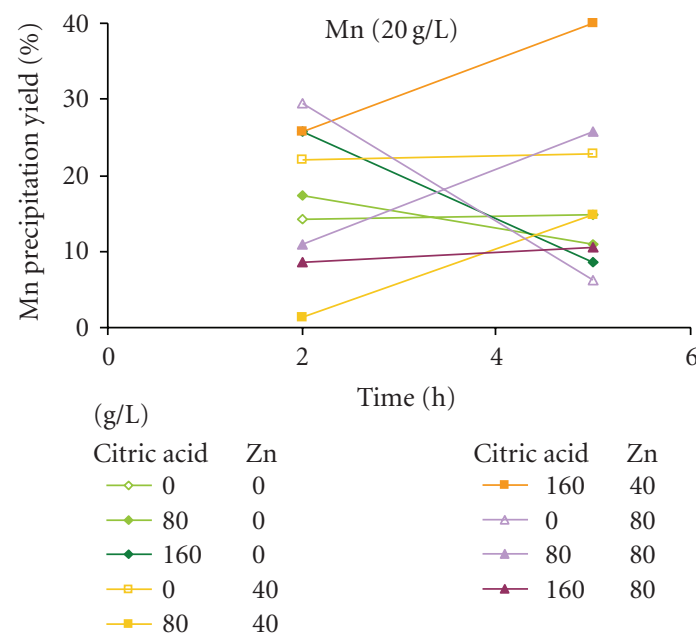

(c)

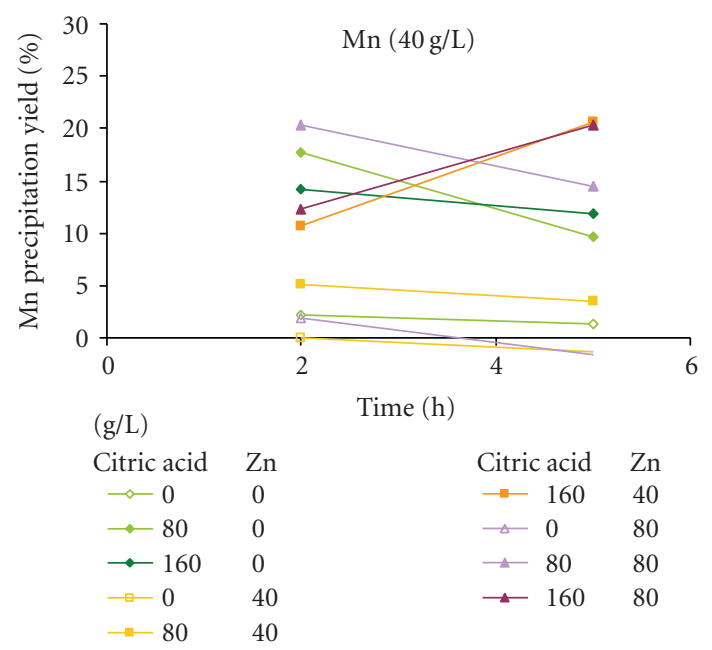

(e)

FIGURE 8: Results of the second series of precipitation tests.

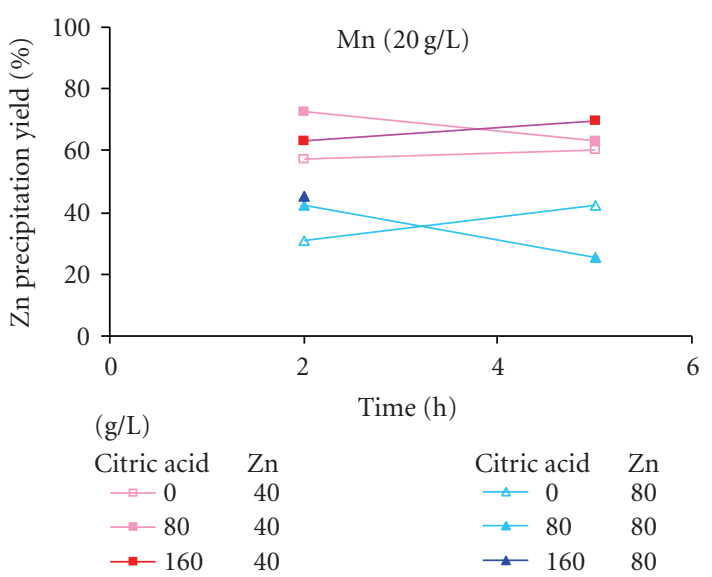

(b)

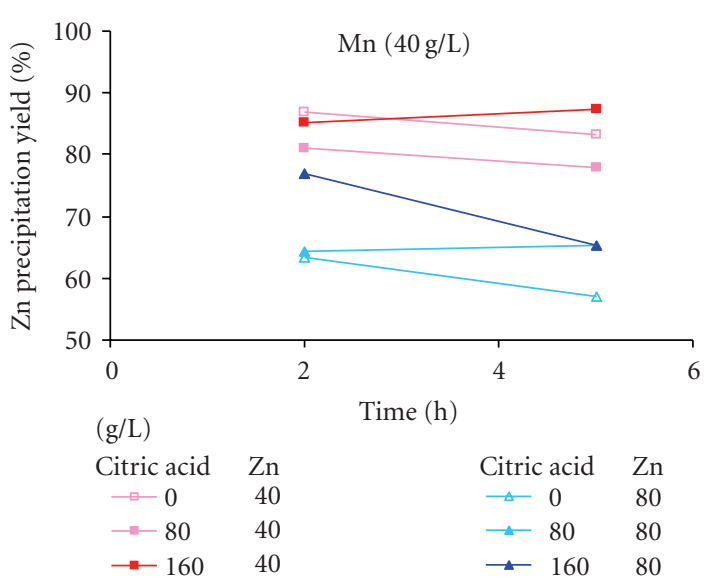

(d) 
quite soluble, as the precipitation was never over 30-35\%. This second set of tests is more representative of real leaching, as the final concentration of sulphuric acid is low: in fact it confirms the results obtained in the first full factorial design. A possible explanation of the trend could be found by using the predominance area diagrams by Medusa software (here not reported): in the investigated conditions (typical leaching experimental concentrations of $\mathrm{Zn}^{2+}, \mathrm{Mn}^{2+}, \mathrm{SO}_{4}{ }^{2-}$, citrate ion), $\mathrm{Zn}$ is present as $\mathrm{ZnHC}_{12} \mathrm{H}_{10} \mathrm{O}_{14}$, while $\mathrm{Mn}$ as $\mathrm{MnH}_{2}\left(\mathrm{C}_{12} \mathrm{H}_{10} \mathrm{O}_{14}\right)^{+}$. Looking at Figure 7 , it is easy to highlight how solubility of that zinc salt is lower than that of the manganese ion, confirming the results of both leaching and the second series of precipitation tests.

\section{Process Analysis}

The experimental results obtained by leaching and precipitation tests suggest a possible flow sheet to recover zinc and manganese from alkaline and $\mathrm{Zn}-\mathrm{C}$ spent batteries.

Collected batteries are sorted to remove those types recycled in other plants, such as Ni-Cd, Li-ion, Ni-MH. Batteries are crushed by a Hazemag impact crusher, and the resulting products are separated in two different fractions by means of sieving $(1.6-2 \mathrm{~mm})$. The coarse fraction is composed by magnetic scraps which are first separated by a magnetic separator, whereas nonferrous scraps are recovered by an Eddy current separator. Remaining plastic and paper films, together with unsorted materials (carbon rods), can be landfilled or incinerated as RDF (Refused Derived Fuels). The fine fraction that has previously been dried (due to the heat developed during crushing) is leached by sulphuric acid and citric acid according to the best conditions found in the present study; the dissolution of manganese and zinc can be lead by a countercurrent leaching to save a large amount of $\mathrm{NaOH}$ in the precipitation stage, as reported in [11]. After that the suspension is filtered by a plate and frame filter, and iron is precipitated by means of $\mathrm{NaOH}$ at $\mathrm{pH}$ 4.8. Thus, the solution undergoes cementation with zinc powder. The cementation step is required to remove certain metals more electropositive than zinc, like $\mathrm{Cu}, \mathrm{Cr}$, $\mathrm{Cd}$, and $\mathrm{Ni}$, which could impair the purity of the precipitated compounds $[19,29]$. The purified solution is then ready for a sequential electrowinning where zinc is recovered at the cathode and mixed manganese oxides such as $\mathrm{Mn}_{2} \mathrm{O}_{3}$ and $\mathrm{Mn}_{3} \mathrm{O}_{4}$ precipitate at the anode side [30]. Spent solution is recycled back to the leaching reactor, since sulphuric acid is regenerated during electrolysis.

\section{Conclusions}

In this paper a reductive-acid leaching was studied for recovery of zinc and manganese from alkaline and zinc-carbon spent batteries. Optimum technical-economical leaching conditions able to leach $100 \%$ of both zinc and manganese are the following: $1.8 \mathrm{M} \mathrm{H}_{2} \mathrm{SO}_{4}$ concentration, $40 \mathrm{~g} \mathrm{~L}^{-1}$ citric acid concentration at $40^{\circ} \mathrm{C}$ with $200 \mathrm{~g} \mathrm{~L}^{-1}$ pulp density. The use of an organic compound like citric acid is an environmentally friendly technique which permits to extract manganese and zinc contained in alkaline and zinc-carbon batteries. The analysis of variance was carried out using the Yates' algorithm on zinc and manganese extraction yields after $5 \mathrm{~h}$ : this analysis showed that the zinc extraction is positively influenced by pulp density and negatively by interaction of citric acid concentration-pulp density, temperature-pulp density, and citric acid-temperature-pulp density. Manganese extraction is promoted by increase of citric acid concentration, temperature, and pulp density whereas is negatively influenced by the contemporary increase of temperature and pulp density.

Precipitation tests on synthetic solutions were also performed to study the recovery of $\mathrm{Zn}$ and $\mathrm{Mn}$ : results showed that a complete separation is not possible, since the quantitative precipitation of zinc oxalate is simultaneously achieved with precipitation of $30 \%$ of manganese. Complete separation of zinc could be achieved by several sequential precipitations by citric acid: zinc and manganese oxalates can be calcined for obtaining pure zinc and manganese oxide. Another recovery process which can be developed involves the purification of solution after the countercurrent leaching for removal of iron and other metal impurities from leach liquor, thus zinc and manganese can be recovered from that solution by a sequential electrolysis.

\section{Acknowledgments}

The authors sincerely acknowledge Mrs Fabiola Ferrante and $\mathrm{Mr}$ Marcello Centofanti for their assistance in XRF characterization and AAS analyses.

\section{References}

[1] European Portable Battery Association, 2008, http://www .epbaeurope.net.

[2] European Union, 2008, http://europa.eu.int.

[3] European Battery Recycling Association, 2008, http://www .ebra-recycling.org.

[4] P. Marini and M. C. Zanetti, "Pre-treatment tests for the recovery of exhaust portable accumulators," in Proceedings of the 23rd International Mineral Processing Congress, pp. 21582162, Istanbul, Turkey, 2006.

[5] D. C. R. Espinosa, A. M. Bernardes, and J. A. S. Tenório, "An overview on the current processes for the recycling of batteries," Journal of Power Sources, vol. 135, no. 1-2, pp. 311319, 2004.

[6] W. Lindermann, Process for the recovery of raw materials from presorted collected waste, especially scrap electrochemical batteries and accumulators (1996), Patent Application US 5 575907.

[7] F. Tedjar, Recycling used electric cells by hydrometallurgical treatment (2003), Patent application WO 03/021 708.

[8] A. Serstevens, Process for the recycling of salt and alkaline batteries (2001), Patent application EP 1148571.

[9] Batrec Process, 2006, http://www.batrec.ch.

[10] L. Toro, F. Vegliò, F. Beolchini, F. Pagnanelli, M. Zanetti, and G. Furlani, Process and plant for the treatment of run-down batteries (2006), Patent application EP 1684369.

[11] I. De Michelis, F. Ferella, E. Karakaya, F. Beolchini, and F. Vegliò, "Recovery of zinc and manganese from alkaline and 
zinc-carbon spent batteries," Journal of Power Sources, vol. 172, no. 2, pp. 975-983, 2007.

[12] C. C. B. M. De Souza and J. A. S. Tenório, "Simultaneous recovery of zinc and manganese dioxide from household alkaline batteries through hydrometallurgical processing," Journal of Power Sources, vol. 136, no. 2, pp. 191-196, 2004.

[13] C. C. B. M De Souza, D. C. De Oliveira, and J. A. S. Tenório, "Characterization of used alkaline batteries powder and analysis of zinc recovery by acid leaching," Journal of Power Sources, vol. 103, no. 1, pp. 120-126, 2001.

[14] S. M. Xará, J. N. Delgado, M. F. Almeida, and C. A. Costa, "Laboratory study on the leaching potential of spent alkaline batteries," Waste Management, vol. 29, no. 7, pp. 2121-2131, 2009.

[15] L. R. S. Veloso, L. E. O. C. Rodrigues, D. A. Ferreira, F. S. Magalhães, and M. B. Mansur, "Development of a hydrometallurgical route for the recovery of zinc and manganese from spent alkaline batteries," Journal of Power Sources, vol. 152, no. 1-2, pp. 295-302, 2005.

[16] A. L. Salgado, A. M. O. Veloso, D. D. Pereira, G. S. Gontijo, A. Salum, and M. B. Mansur, "Recovery of zinc and manganese from spent alkaline batteries by liquid-liquid extraction with Cyanex 272," Journal of Power Sources, vol. 115, no. 2, pp. 367 373, 2003.

[17] N. B. Devi, K. C. Nathsarma, and V. Chakravortty, "Extraction and separation of $\mathrm{Mn}$ (II) and $\mathrm{Zn}$ (II) from sulphate solutions by sodium salt of Cyanex 272," Hydrometallurgy, vol. 45, no. 1-2, pp. 169-179, 1997.

[18] N. Vatistas, M. Bartolozzi, and S. Arras, "The dismantling of the spent alkaline zinc manganese dioxide batteries and the recovery of the zinc from the anodic material," Journal of Power Sources, vol. 101, no. 2, pp. 182-187, 2001.

[19] F. Ferella, I. De Michelis, and F. Vegliò, "Process for the recycling of alkaline and zinc-carbon spent batteries," Journal of Power Sources, vol. 183, no. 2, pp. 805-811, 2008.

[20] E. Sayilgan, T. Kukrer, F. Ferella, A. Akcil, F. Veglio, and M. Kitis, "Reductive leaching of manganese and zinc from spent alkaline and zinc-carbon batteries in acidic media," Hydrometallurgy, vol. 97, no. 1-2, pp. 73-79, 2009.

[21] G. Xi, Y. Li, and Y. Liu, "Study on preparation of manganesezinc ferrites using spent Zn-Mn batteries," Materials Letters, vol. 58, no. 7-8, pp. 1164-1167, 2004.

[22] J. Nan, D. Han, M. Cui, M. Yang, and L. Pan, "Recycling spent zinc manganese dioxide batteries through synthesizing Zn-Mn ferrite magnetic materials," Journal of Hazardous Materials, vol. 133, no. 1-3, pp. 257-261, 2006.

[23] E. Sayilgan, T. Kukrer, G. Civelekoglu et al., "A review of technologies for the recovery of metals from spent alkaline and zinc-carbon batteries," Hydrometallurgy, vol. 97, no. 3-4, pp. 158-166, 2009.

[24] J.-W. Kim, S. Barrington, J. Sheppard, and B. Lee, "Nutrient optimization for the production of citric acid by Aspergillus niger NRRL 567 grown on peat moss enriched with glucose," Process Biochemistry, vol. 41, no. 6, pp. 1253-1260, 2006.

[25] D.C. Montgomery, Design and Analysis of Experiments, John Wiley \& Sons, New York, NY, USA, 3rd edition, 1991.

[26] D. M. Himmelblau, Process Analysis by Statistical Methods, John Wiley \& Sons, New York, NY, USA, 3rd edition, 1978.

[27] N. S. Gajbhiye, U. Bhattacharya, and V. S. Darshane, "Thermal decomposition of zinc-iron citrate precursor," Thermochimica Acta, vol. 264, pp. 219-230, 1995.

[28] Hydra/Medusa software, Chemical Equilibrium Diagrams, http://www.kemi.kth.se/medusa.
[29] B. S. Boyanov, V. V. Konareva, and N. K. Kolev, "Purification of zinc sulfate solutions from cobalt and nickel through activated cementation," Hydrometallurgy, vol. 73, no. 1-2, pp. 163-168, 2004.

[30] F. Ferella, G. Furlani, M. Navarra et al., "Hydrometallurgical plant to recycle alkaline and $\mathrm{Zn}-\mathrm{C}$ spent batteries: process and economic analysis," in Proceedings of the 2 nd International Conference on Engineering for Waste Valorization, Patras, Greece, 2008. 

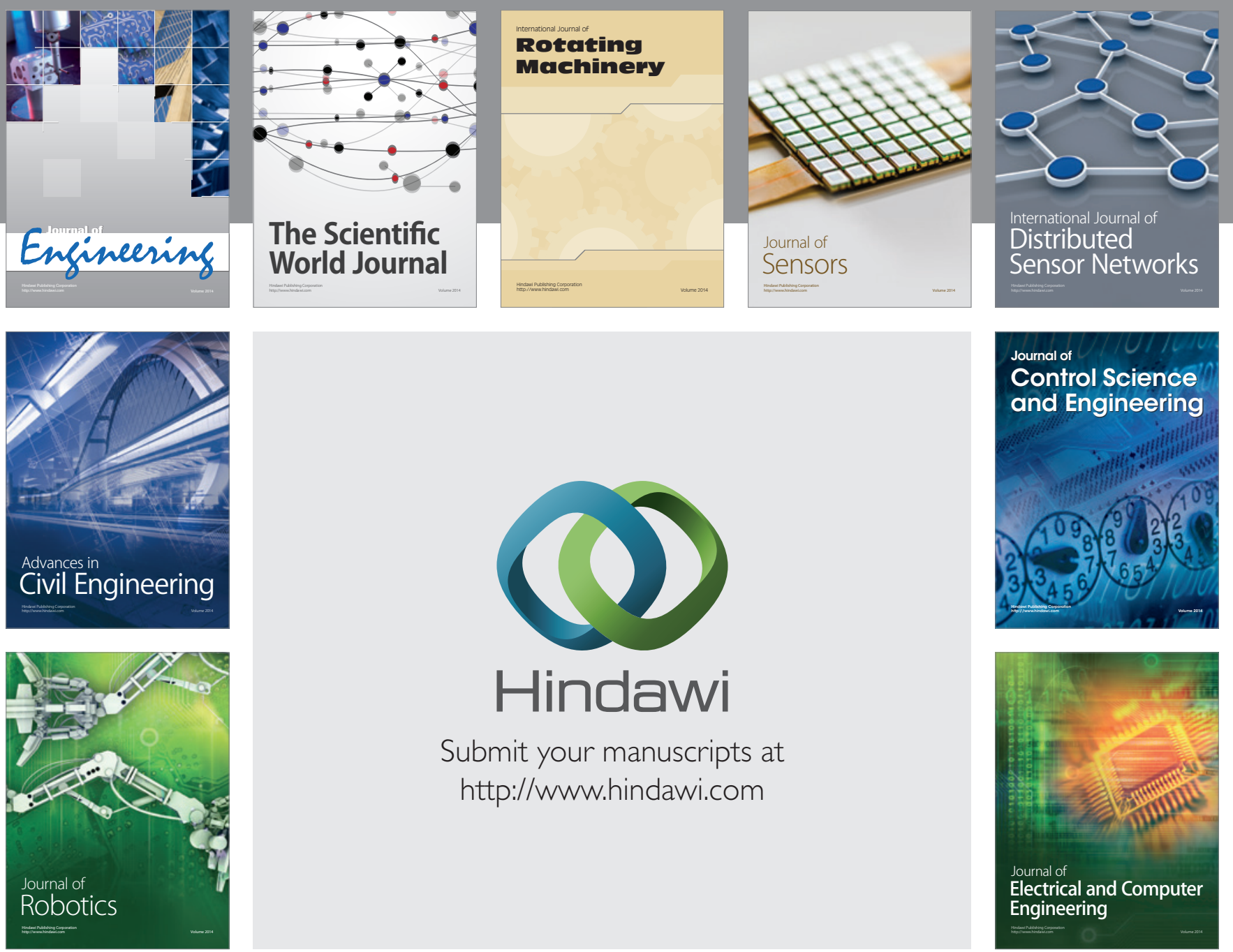

Submit your manuscripts at

http://www.hindawi.com
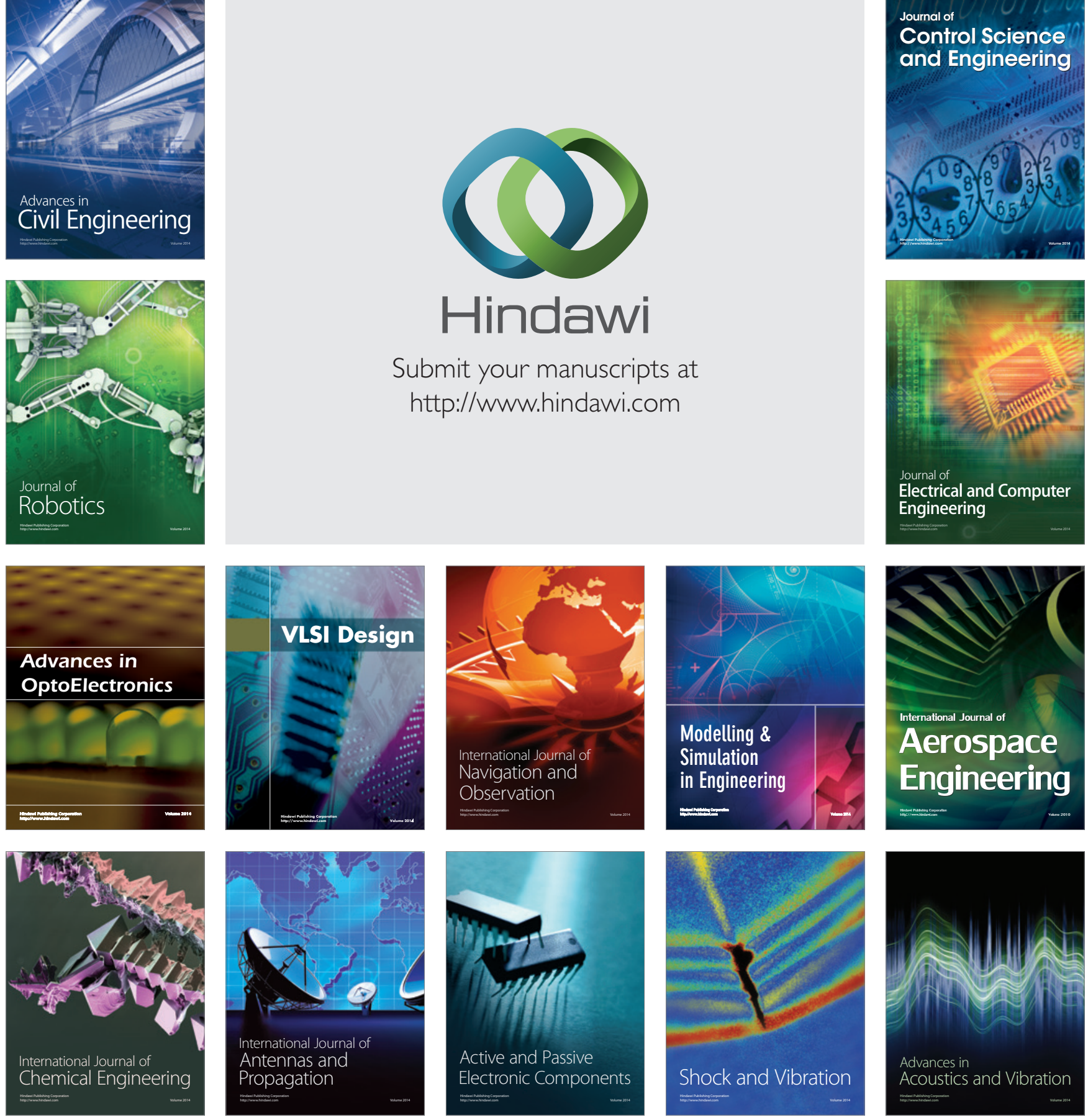